\title{
VACATION NOTES IN THE ADIRONDACKS
}

By W. E. Britron, New Haven, Conn.

It was the writer's good fortune to spend two weeks of his vacation, July 8 to July 22, 1911, in the town of Jay, Essex County, N. Y., at an altitude of over 1,000 feet. The following entomological observations were made there, and most of the species herein mentioned were collected.

Acres of alders on the hillsides and along streams had been defoliated by the alder flea-beetle, Haltica bimarginata Say (=alni Harr.). In some cases the bushes were bare, but usually the network of the leaves still remained, and turning brown gave them the appearance of having been scorched by fire. The adult is one of the largest species of the genus Haltica, is dark blue and with a longitudinal fold on the outer margins of the wing covers.

Another and smaller flea-beetle, Phyllodecta vittellina Linn. (=vulgatissima Linn.) was feeding upon the terminal leaves of low-growing willows along the banks of the Ausable River.

The forest tent caterpillar, Malacosoma disstria Hubn., had evidently been quite abundant earlier in the season, as the separate empty cocoons were present on the trunk of nearly every tree, including pines, and on fences and stone walls. On the under side of large branches of apple trees one could see patches five or six inches in diameter of the cast skins or molts of the caterpillars. These trees also showed that considerable eating had been done by the caterpillars earlier in the season before the trees had ceased growing.

The underbrush in the pine woods, near the writer's cabin, was commonly infested by a soft scale, probably Lecanium corni Bouché. The brown empty shells were still clinging to the twigs, and the young were well established along the veins of the leaves as well as on the bark of the twigs. Many twigs and some small bushes had already been killed by this insect, which was noticed on elm, hazel, hop hornbeam or ironwood, sugar maple, yellow birch, paper birch, choke cherry, black cherry and bird or pigeon cherry.

Oyster shell scale was abundant, and one scrub apple in a pasture had been killed outright by it.

In climbing Mount Wainwright (one of the lesser peaks) I noticed a paper birch which had been attacked by the bronze birch borer, Agrilus anxius Gory, the spiral ridges caused by the tunneling of the larvæ showing prominently on the upper branches.

In the fields and pastures the grass was being destroyed by hordes 
of grasshoppers, the most abundant species seemingly being Camnula pellucida Scudd.

Collecting in this region was especially poor because of the extreme drought, which was the most severe in the memory of the oldest residents. In the Lepidoptera, the Mourning Cloak, Euvanessa antiopa Linn. and the Compton Tortoise Grapta j-album Boisdv. \& Lec., Hadena arctica Boisdv. and Epizeuxis lubricalis Geyer were very common in the pine woods around the cabins. The imported cabbage butterfly Pontia (Pieris) rape Linn. and P. napi Linn. were both rather abundant. Polygonia faunus Edw. and $P$. progne Cram. flitted about the cabin among the pine trees, and a few specimens were taken. The rarest capture, perhaps, was a perfect female specimen of Plusia balluca Geyer, which was brought to me one day by the landlady, who found it in the house. I afterwards found a fresh wing of the same species at the foot of a large pine, showing that tragedies occur in entomology.

Five specimens of Caripeta angustiorata Walk. and one of $C$. divisata Walk. were taken, and amongst the lot are several small geometrids, some of which have not yet been identified. Few noctuids were collected.

In the Diptera, which were mostly common species, there was a single example each of Dasyllis posticata Say and Psilocephala rufiventris Loew.

In the Coleoptera Leptura canadensis Oliv. was common flying about in the pine woods; and Typocerus velutinus Oliv. was abundant on flowers of Spirca salicifolia. One example of Cicindela longilabris Say was captured. One specimen each of Buprestis maculiventris Say, Corymbites ceripennis Kirby, and a female specimen of Odontceus obesus L C. C., the latter originally described from California, were kindly identificd for me by Mr. C. A. Frost.

A number of interesting insects in other orders were also collected, but many of these are still undetermined.

EIm Leaf Beetle (Galerucella lufeola Mull.). This pest has been excessively abundant and destructive the past season on Long Island, throughout the Hudson valley and in other sections of the state where it has become established. The elms in many villages were so seriously affected that practically all the leaves were destroyed by midsummer. This serious injury also occurred on groups of elms or even roadside trees in the country. It is undoubtedly true that the damage was greatly accentuated by drought, yet it seems very probable that automobiles and trolley cars have been important factors in distributing an otherwise local though very prolific insect and, as a consequence, are indirectly responsible.

E. P. FelT. 